\title{
Does impaired cardiac function affect peripheral arterial angioplasty outcomes?
}

\author{
Kok H Yap ${ }^{1}$, Yew L Woo ${ }^{1}$, Anna LW Tam², ${ }^{*}$ Phong T Lee ${ }^{1}$, Yi C Tham', Nern H Kao ${ }^{1}$ \\ From World Society of Cardiothoracic Surgeons 25th Anniversary Congress, Edinburgh \\ Edinburgh, UK. 19-22 September 2015
}

\section{Background/Introduction}

Peripheral vascular disease is commonly associated with concomitant coronary heart disease and congestive heart failure.

\section{Aims/Objectives}

We aim to perform a cohort study to evaluate if revascularization of lower limb is sufficient for wound healing in patients with impaired cardiac function.

\section{Method}

We performed a retrospective study in a tertiary vascular surgical centre on patients with elective lower limb angioplasty for critical limb ischaemia from June 2011 to June 2012. 190 patients were included in this study. Pre-operative demographics, comorbidities, post-operative 30-day mortality, amputation and re-intervention data were collected. The cardiac function was defined as poor $(\geq 40 \%)$, moderate $(40-54 \%)$, and good $(\leq 55 \%)$. Univariate and multivariate analyses were done to identify the pre-operative morbidities and whether cardiac function affects the outcomes for these groups of patients. The outcomes measured were re-intervention, limb amputation, wound re-debridement, 30-day post-operative mortality.

\section{Results}

Our patient population consisted of 190 patients with 97 males and 93 females. The most common pre-operative morbidity is diabetes (85\%). Overall 30-day mortality rate is $5.2 \%$. Poor cardiac function $(\mathrm{p}=0.013)$ and ischaemic heart disease (0.032) were significantly associated with post-operative mortality in univariate analysis. In multivariate analysis, poor cardiac function

${ }^{2}$ Department of Cardiothoracic Surgery, National Heart Centre Singapore, Singapore, 169609, Singapore

Full list of author information is available at the end of the article showed significant association with post-op mortality ( $\mathrm{p}$ $=0.045)$. Below knee angioplasty was significantly associated with the need in amputation in univariate $(\mathrm{p}=$ $0.014)$ and multivariate analyses (0.02).

\section{Discussion/Conclusion}

Poor EF is associated with post-angioplasty 30-day mortality. Below knee angioplasty appears to be associated with higher amputation risk. This is the first evidence in the literature that show the association between impaired heart function and adverse outcome after lower limb angioplasty for critical limb ischemia.

\section{Authors' details}

'Department of General Surgery, Changi General Hospital, Singapore, Singapore, 529889, Singapore. '2Department of Cardiothoracic Surgery, National Heart Centre Singapore, Singapore, 169609, Singapore.

Published: 16 December 2015

doi:10.1186/1749-8090-10-S1-A114

Cite this article as: Yap et al:: Does impaired cardiac function affect peripheral arterial angioplasty outcomes? Journal of Cardiothoracic Surgery 2015 10(Suppl 1):A114.

Submit your next manuscript to BioMed Central and take full advantage of:

- Convenient online submission

- Thorough peer review

- No space constraints or color figure charges

- Immediate publication on acceptance

- Inclusion in PubMed, CAS, Scopus and Google Scholar

- Research which is freely available for redistribution 